\title{
Pengaruh Partisipasi Anggaran dan Gaya Kepemimpinan Terhadap Kinerja Manajerial dengan Job Relevant Information sebagai Pemoderasi
}

\author{
Muhammad Syukri ${ }^{1}$ \\ Fakultas Ekonomi dan Bisnis \\ Universitas Mataram, Indonesia. \\ Email: m.syukri513@gmail.com
}

\author{
Ni Ketut Surasni2 \\ Fakultas Ekonomi dan Bisnis \\ Universitas Mataram, Indonesia.
}

\author{
Lalu M. Furkan ${ }^{3}$ \\ Fakultas Ekonomi dan Bisnis \\ Universitas Mataram, Indonesia.
}

\begin{abstract}
ABSTRAK
Penelitian bertujuan mengungkap pengaruh partisipasi anggaran dan gaya kepemimpinan terhadap kinerja manajerial serta pengaruh job relevant information dalam memperkuat pengaruh hubungan partisipasi anggaran dan gaya kepemimpinan terhadap kinerja manajerial. Sumber data pada penelitian menggunakan kuesioner yang disebar pada 43 OPD Kabupaten Lombok Barat. Hasil Penelitian menunjukkan partisipasi anggaran dan gaya kepemimpinan berpengaruh terhadap kinerja manajerial dan nilai orginal sampel menunjukkan positif bararti partisipasi anggaran dan gaya kepemimpinan memiliki hubungan yang searah dengan kinerja manajerial, job relevant information tidak mampu memperkuat pengaruh partisipasi anggaran terhadap kinerja manajerial dan nilai original sampel menunjukkan negatif job relevant information tidak mampu memperkuat pengaruh gaya kepemimpinan terhadap kinerja manajerial dan nilai original sampel menunjukkan negatif.
\end{abstract}

Kata Kunci : Partisipasi Anggaran; Gaya Kepemimpinan; Job Relevant Information; Kinerja Manajerial.

\section{Effect of Budget Participation and Leadership Style on Managerial Performance with Job Relevant Information as Moderating}

\section{ABSTRACT}

The study aims to reveal the effect of budgetary participation and leadership style on managerial performance as well as the influence of job relevant information in strengthening the influence of budgetary participation relationships and leadership style on managerial performance. Sources of data in the study using a questionnaire distributed to 43 West Lombok Regency $O P D$. The results showed budget participation and leadership style involved managerial performance and the original sample value showed positive budget participation and leadership style related to the direction of managerial performance, work related information did not support job relevant information did not support improvement of leadership style on managerial performance and sample value Original shows negative.

Keywords: Budgetary Participation; Leadership Style; Job Relevant Information Managerial Performance.

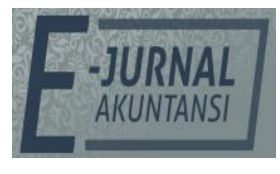

E-JA

e-Jurnal Akuntansi e-ISSN 2302-8556

Vol. 29 No. 3

Denpasar, Desember 2019

Hal. 987-996

Artikel masuk:

3 September 2019

Tanggal diterima: 20 November 2019 


\section{PENDAHULUAN}

Anggaran merupakan suatu instrumen penting di dalam organisasi bisnis (laba) maupun dalam organisasi pemerintahan (nirlaba). Anggaran sendiri merupakan bagian dari aktivitas yang dilakukan secara rutin dan terus-menerus. Menurut (Mardiasmo, 2002:61) anggaran merupakan instrumen akuntabilitas atas pengelolaan dana publik dan pelaksanaan program-program yang dibiayai dengan uang publik. Dalam akutansi pemerintahan, anggaran merupakan dasar pelaksanaan suatu kegiatan yang dapat dibiayai oleh keuangan negara/daerah ((Bahtiar Arif dan Iskandar, 2009:121). Selain itu partisipasi dalam penyusunan anggaran salah satu unsur yang sangat penting yang menekankan pada proses kerjasama dari berbagai pihak, baik bawahan maupun manajer level atas. Partisipasi anggaran akan melibatkan dua kelompok atau lebih yang mempengaruhi dalam pembuatan keputusan dimasa akan datang pada suatu organisasi untuk meningkatkan kinerjanya.

Partisipasi penyusunan anggaran dilakukan dengan tujuan agar anggaran yang ditetapkan nantinya bisa sesuai dengan keadaan yang terjadi. Dengan demikian penyusunan anggaran secara partisipatif diharapkan akan meningkatkan kinerja manejerial (Sucitrawati dan Sari 2017). Kinerja manajerial dalam suatu proses penyusunan anggaran tersebut, baik secara langsung maupun tidak langsung akan meningkatkan kesadaran mereka akan tugas dan tanggung jawab yang telah dibebankan. Hal ini juga akan menimbulkan komitmen tersebut bahwa anggaran yang disusun itu juga merupakan tujuan mereka. Dengan demikian, hasil yang didapat dari penyusunan anggaran itu akan dapat merefleksikan tujuan dari semua pihak yang terlibat dalam organisasi.

Selain anggaran, gaya kepemimpinan juga dapat menjadi pedoman yang baik dalam meningkatkan kinerja manajerial dan cukup efektif dalam memberikan pengarahan kepada bawahan untuk mencapai tujuan organisasi, meningkatnya kinerja manajerial dalam suatu organisasi, secara langsung maupun tidak langsung akan berdampak pula kepada kinerja organisasi tersebut secara keseluruhan. Semakin baik terlihat kinerja manajerial, maka bisa dikatakan semakin baik pula kinerja organisasi tersebut. Untuk organisasi pemerintahan (nirlaba), semakin baik kinerja manajerial maka pelayanan publik yang diberikan kepada masyarakatpun akan semakin baik pula. Kepemimpinan yang berkualitas dalam organisasi akan menghasilkan kesuksesan bagi organisasi. Kepemimpinan dapat diartikan suatu proses dimana seseorang dapat memimpin, membimbing, mengarahkan ataupun mempengaruhi pikiran dan tingkah laku orang lain untuk mencapai tujuan tertentu.

Job Relevant Information dikatakan dapat meningkatkan kinerja manajerial melalui pemberian perkiraan yang lebih akurat mengenai lingkungan sehingga dapat dipilih rangkaian tindakan efektif yang terbaik (Kren, 1992). Dengan hal ini akan memungkinkan perkiraan yang lebih akurat atas alternatif tindakan yang diambil saat kondisi lingkungan dalam suatu organisasi tiba-tiba berubah. Informasi Job Relevant Information membantu manajer dalam memberikan informasi mengenai berbagai macam alternative pengambilan keputusan dan tindakan yang dibutuhkan untuk mencapai tujuan dari penyusunan anggaran. Hubungan antara partisipasi dan Job Relevant Information terjadi pada saat 
dimana bawahan diberikan kesempatan untuk ikut memberikan masukan berupa informasi yang dimilikinya kepada atasan sehingga atasan yang berperan dalam penyusunan anggaran akan memperoleh pemahaman yang lebih baik tentang pengetahuan yang relevan dengan tugas, (Yusfaningrum, 2005).

Job Relevant Information dalam penelitian ini merupakan variabel moderating yang secara teoritis mempengaruhi (memperkuat atau memperlemah) hubungan antara partisipasi anggaran, gaya kepemimpinan terhadap kinerja manajerial. Berdasarkan variabel-variabel yang sedang diteliti dapat diketahui bahwa partisipasi anggaran bisa berpengaruh langsung terhadap kinerja manajerial akan tetapi partisipasi dalam penyusunan anggaran bisa juga berpengaruh secara tidak langsung karena adanya variabel Job Relevant Information sebagai variabel moderating.

Berdasarkan goal setting Thory (Locke, 1990), pemerintah Kabupaten Lombok Barat dapat mengambil langkah apa saja yang menjadi tujuannya dan apa yang akan diharapkan atas hasil kinerjanya. . Pemerintah di daerah dituntut untuk lebih fokus pada pembenahan pelayanan publik kepada masyarakat. Kondisi ini yang mendorong berkembangnya wacana perlunya reformasi anggaran agar pengalokasian anggaran lebih berorientasi pada kepentingan publik melalui partisipasi anggaran dan gaya kepemimpinan. Kedudukan penganggaran sebagai integrasi antara pelaporan penyelenggaraan kegiatan pemerintahan dan sistem keuangan menjadi sangat penting dalam rangka mereformasi birokrasi pemerintahan (Lembaga Administrasi Negara, 2007).

Pemerintah Kabupaten Lombok Barat memiliki tingkat pelayanan publik berada pada zona merah, skor diberikan Ombudsman RI Perwakilan NTB (ORI NTB) di Mataram , Rabu (12/12/2018) seperti pada tabel 1 dibawah ini :

Tabel 1. Skor penilaian Ombudsman RI Perwakilan NTB (ORI NTB)

\begin{tabular}{clccl}
\hline No & \multicolumn{1}{c}{ Kabupaten } & Skor & Urutan & Zona \\
\hline 1 & Lombok Utara & 93,87 & 14 & Hijau \\
2 & Lombok Tengah & 63,49 & 113 & Kuning \\
3 & Dompu & 60,41 & 121 & Kuning \\
4 & Lombok Timur & 58,22 & 127 & Kuning \\
5 & Sumbawa & 57,69 & 128 & Kuning \\
6 & Bima & 56,97 & 133 & Kuning \\
7 & Lombok Barat & 44,68 & 162 & Merah
\end{tabular}

Sumber: Harianto, tahun 2018. Diakses pada tanggal 2 April 2019, pukul 21.30, dari https:// news.detik.com/berita/d-4339460/pelayanan-publik-kabupatenlombok-barat-paling-buruk-di-ntb

Tabel 1. memperlihatkan buruknya pelayanan publik pada pemerintahan Kabupaten Lombok Barat perlu penanganan lebih lanjut dan keseriusan para pimpinan untuk memperbaiki hal tersebut guna meningkatkan kinerjanya. Dari 199 kabupaten yang dinilai di Indonesia, hanya 1 kabupaten di NTB yang memenuhi kriteria kepatuhan tinggi (zona hijau), yaitu Kabupaten Lombok Utara dengan skor 93,87 di urutan 14, ada 5 kabupaten di NTB yang berada pada tingkat kepatuhan sedang yang ditandai dengan zona kuning, yaitu Lombok Tengah dengan nilai 63,49 dan berada di posisi 113. Kabupaten Dompu dengan nilai 60,41 berada pada posisi 121, Kabupaten Lombok Timur dengan nilai 58,22 menempati posisi 127. Sementara untuk Kabupaten Sumbawa Barat dengan skor 
nilai 57,69 pada posisi 128 dan Kabupaten Bima dengan nilai 56,97 berada di posisi 133. Hanya terdapat 1 kabupaten yang berada di level kepatuhan rendah yang posisinya pada zona merah dengan nilai 44,68 menempati urutan 162, yaitu Kabupaten Lombok Barat. Periode pengambilan data penilaian dilakukan secara serentak di bulan Mei-Juli 2018. Penilaian ini dilakukan setiap satu tahun sekali.

Penelitian ini memiliki tema yang berbeda dengan peneliti terdahulu yaitu menghubungkan gaya kepemimpinan terhadap kinerja manajerial dengan di moderasi oleh variabel job relevant information. Saputra dan Natassia (2014) melakukan penelitian yang menyatakan bahwa terdapat pengaruh yang positif dan signifikan antara gaya kepemimpinan terhadap kinerja karyawan Badan Pusat Statistik (BPS) Kota Padang, yang berarti pimpinan Badan Pusat Statistik (BPS) Kota Padang lebih meningkatkan dan menerapkan gaya kepemimpinannya dengan lebih baik lagi agar motivasi yang dimiliki oleh karyawan Badan Pusat Statistik (BPS) Kota Padang lebih meningkat pula. Berbeda dengan penelitian yang dilakukan oleh Putri dan Adiguna (2014) yang menyatakan bahwa gaya kepemimpinan tidak memiliki pengaruh signifikan terhadap kinerja manajerial. Penelitian tentang pengaruh gaya kepemimpinan terhadap kinerja manajerial pernah dilakukan oleh Satria dan Priatna (2012), Fitri et al (2013), Indriayti (2017) yang menyatakan kinerja manajerial dipengaruhi oleh gaya kepemimpinan.

Kebaruan dari penelitian ini adalah dalam hal pengukuran yaitu memunculkan variabel moderasi yang digunakan. Variabel yang digunakan oleh peneliti terdahulu antara lain Satria dan Priatna (2012), Saputra dan Natassia (2014), Putri dan Adiguna (2014), Fitri et al (2013), Indriayti (2017) adalah tidak ada variabel moderasi yang digunakan, sedangkan varibel yang digunakan dalam peneliti saat ini mencoba memunculkan variabel Job Relevant Information sebagai pemoderasi. Alasan digunakannya Job Relevant Information sebagai pemoderasi adalah dapat memberikan bukti bahwa informasi yang relevan dalam tugas mampu memperkuat pengaruh gaya kepemimpinan dalam meningkatkan kinerja manajerial pada masing-masing OPD Kabupaten Lombok Barat.

Berdasarkan latar belakang yang telah dijelaskan di atas, peneliti ingin mengungkapkan apakah partisipasi anggaran berpengaruh terhadap kinerja manajerial pada Pemerintah Kabupaten Lombok Barat. Selain itu, peneliti juga ingin mengungkapkan apakah gaya kepemimpinan berpengaruh terhadap kinerja manajerial pada Pemerintah Kabupaten Lombok Barat. Selanjutnya apakah Job Relevant Information mampu memperkuat pengaruh variabel partisipasi anggaran terhadap kinerja manajerial dan terkahir apakah Job Relevant Information mampu memperkuat pengaruh variabel gaya kepemimpinan terhadap kinerja manajerial pada pemerintah Kabupaten Lombok Barat.

Landasan teori yang digunakan dalam penelitian ini adalah teori penetapan tujuan (goal setting theory) oleh (Locke, 1990), selanjutnya akan dijelaskan mengenai masing-masing variabel yang digunakan dalam penelitian ini yakni: partisipasi anggaran, gaya kepemimpinan, job relevant information dan kinerja manajerial. Dengan adanya goal setting theory akan mendorong seseorang untuk berkreatifitas/menemukan metode yang lebih baik dalam melakukan pekerjaan (Locke, 1990). Teori penetapan tujuan (goal setting theory) menguraikan 
hubungan antara tujuan yang ditetapkan dengan prestasi kerja. Model penelitian yang digunakan adalah sebagai berikut:

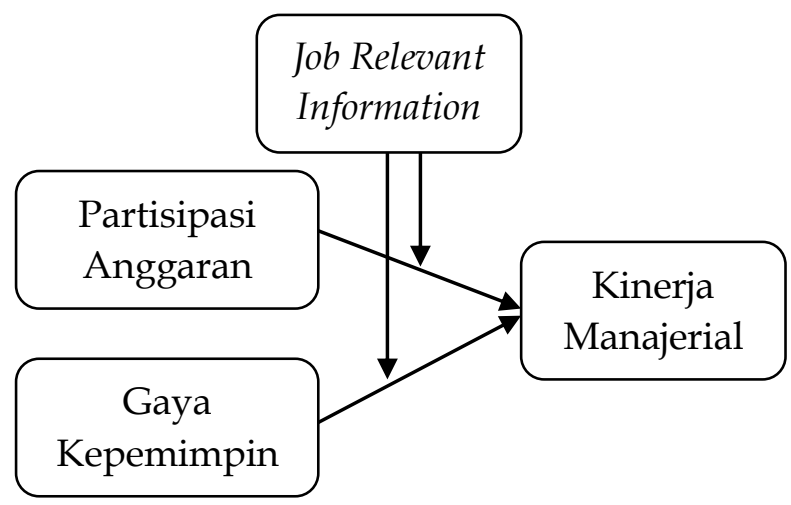

\section{Gambar 1. Model Penelitian}

Sumber : Data Penelitian, 2019

Partisipasi bawahan dalam penyusunan anggaran dan peran anggaran sebagai pengukur kinerja memiliki kaitan yang cukup erat. Browell (1982) dalam Vebyana (2003) mengemukakan bahwa partisipasi anggaran berhubungan dengan luasnya keterlibatan manajer dan memiliki pengaruh dalam penentuan anggaran yang kinerjanya akan dievaluasi dan dihargai atas pencapaian target anggaran yang ditetapkan. Partisipasi penganggaran memiliki pengaruh positif dalam memotivasi manajer (Govindarajan, 1992 dalam Hehanusa, 2010), yaitu adanya kecenderungan lebih besar dari bawahan untuk menerima target anggaran bila diikutsertakan memegang kendali dibandingkan anggaran tersebut ditetapkan secara sepihak. Akibat bawahan diikutsertakan dalam penetapan anggaran secara partisipasi akan mendorong bawahan terikat pada komitmen yang lebih tinggi untuk mencapai kinerja. Menurut Sucitrawati dan Sari (2017), Gunawan dan Santioso (2015), Putri dan Adiguna (2014), Nazaruddin dan Setyawan (2012), Dianawati (2009), Adrianto (2008), dalam penelitiannya menyatakan bahwa partisipasi penyusunan anggaran berpengaruh positif terhadap kinerja manajer. Berdasarkan kajian teori dan penelitian terdahulu dapat ditarik hipotesis sebagai berikut:

$\mathrm{H}_{1}$ : Semakin tinggi partisipasi anggaran, maka semakin baik kinerja manajerial.

Dharma (1992:114) Gaya kepemimpinan seseorang adalah pola perilaku yang diperlihatkan seseorang pada waktu berupaya mempengaruhi aktifitas orang lain seperti yang dipersepsikan orang tersebut. Dalam mengelola suatu organisasi tidak terlepas dari faktor pemimpin dalam organisasi tersebut dan bagaimana sikap yang ditunjukkan oleh bawahan dalam melaksanakan tugas untuk mencapai tujuan. Kepemimpinan yang baik adalah pemimpin yang mampu mempengaruhi dan menggerakkan bawahannya sehingga bawahannya akan bekerja lebih giat, bersedia untuk bekerja sama dan mampu disiplin dalam bekerja. Gaya kepemimpinan ditunjang mampunya bawahan melaksanakan tugas dapat menjadi pemicu meningkatnya kinerja manajerial. Hal ini di perkuat oleh penelitian Indriyati (2017), Saputra dan Natassia (2014), Satria dan Priatna (2012), Soleman (2012) sehingga dapat diambil kesimpulan bahwa gaya kepemimpinan memiliki pengaruh yang signifikan terhadap kinerja manajerial dan hipotesis yang dirumuskan sebagai berikut: 
$\mathrm{H}_{2}$ : Semakin partisipatif gaya kepemimpinan, maka semakin baik kinerja manajerial.

Informasi selama proses partisipasi anggaran akan meningkatkan kemampuan individual dalam hal pengambilan keputusan sehingga dapat meningkatkan kinerja. Job relevant information memperkuat partisipasi anggaran karena memberikan prediksi akurat atas kondisi lingkungan dan memberikan seleksi yang lebih efektif untuk melakukan tindakan terbaik. Informasi yang sesuai dengan pekerjaan bisa memperkuat pengaruh partisipasi anggaran dengan kinerja manajerial. Penelitian dilakukan oleh Nazaruddin dan Setyawan (2012) menunjukkan bahwa Partisipasi penyusunan anggaran berpengaruh positif terhadap kinerja aparat pemerintah daerah dengan job relevant information sebagai variabel moderasi sehingga penelitian dirumuskan sebagai berikut:

$\mathrm{H}_{3}$ : Semakin tinggi job relevan information maka semakin memperkuat pengaruh partisipasi anggaran terhadap kinerja manajerial.

Jogiyanto (1999:692) mendifinisikan informasi sebagai hasil dari pengolahan data dalam suatu bentuk yang lebih berguna dan lebih berarti bagi penerimanya yang menggambarkan suatu kejadian - kejadian (event) yang nyata (fact) yang digunakan untuk pengambilan keputusan. Seorang pimpinan yang memiliki informasi yang akurat dan lengkap yang berhubungan dengan tugas akan meningkatkan kinerja manajerial dalam mencapai target yang telah di tetapkan. Informasi yang sesuai dengan pekerjaan bisa memperkuat pengaruh gaya kepemimpinan dengan kinerja manajerial dan dapat ditarik hipotesis sebagai berikut:

$\mathrm{H}_{4}=$ Semakin tinggi job relevan information maka semakin memperkuat pengaruh gaya kepemimpinan terhadap kinerja manajerial.

\section{METODE PENELITIAN}

Jenis penelitian yang digunakan yaitu penelitian deskriptif dan penelitian empiris. Penelitian deskriptif adalah penelitian terhadap masalah-masalah berupa fakta-fakta saat ini dari suatu populasi (Indriantoro dan Supomo, 2002:26), sedangkan penelitian empiris merupakan penelitian terhadap fakta empiris yang diperoleh berdasarkan observasi atau pengalaman (Indriantoro dan Supomo, 2002:29). Penelitian dilakukan di lingkungan Organisasi Perangkat Daerah (OPD) Pemerintah Kabupaten Lombok Barat. Alasan dipilihnya Pemerintah Kabupaten Lombok Barat sebagai lokasi penelitian didasarkan pada pemberian skor penilaian kepatuhan untuk penyelenggaraan pelayanan publik oleh Ombudsman RI Perwakilan NTB (ORI NTB).

Populasi yang digunakan dalam penelitian ini adalah pejabat struktural pada Organisasi Perangkat Daerah (OPD) Kabupaten Lombok Barat Tahun 2018 yang berjumlah 847 pada Kabupaten Lombok Barat, sedangkan teknik penentuan sampel yang digunakan dalam penelitian ini adalah Probability Sampling. Probability Sampling adalah tekhnik pengambilan untuk memberikan peluang yang sama pada setiap anggota populasi untuk dipilih menjadi anggota sampel (Riduwan, 2009:58). pengambilan sampel menggunakan rumus dari Taro Yamane yang dikutip oleh (Rakhmat, 1998:82) sebagai berikut: 


$$
n=\frac{N}{N \cdot d^{2}+1}
$$

Dimana : $\mathrm{n} \quad=$ Jumlah Sampel

$\mathrm{N} \quad=$ Jumlah Populasi

$\mathrm{d}^{2} \quad=$ Presisi yang ditetapkan

Berdasarkan rumus diatas di ketahui $\mathrm{N}=847$ responden dan tingkat presisi yang di tetapkan sebesar $10 \%$. Diperoleh sampel sebagai berikut :

$n=\frac{N}{N \cdot d^{2}+1}=\frac{847}{847 x 0,1^{2}+1}=\frac{847}{(847)(0,01)+1}=\frac{847}{9,47}=89,44 \approx 89$ responden

Nama-nama OPD Kabupaten Lombok Barat yang dijadikan sampel dapat dilihat pada tabel 2sebagai berikut:

Tabel 2. Daftar Nama OPD Kabupaten Lombok Barat

\begin{tabular}{clc}
\hline No & \multicolumn{1}{c}{ Nama Organisasi Perangkat Daerah (OPD) } & Responden \\
\hline 1 & Sekretariat Daerah & 3 \\
2 & Sekretariat Dewan Perwakilan Rakyat Daerah & 3 \\
3 & Inspektorat Kabupaten & 3 \\
4 & Dinas Pendidikan dan Kebudayaan & 2 \\
5 & Dinas Kesehatan & 2 \\
6 & Dinas Sosial & 2 \\
7 & Dinas Pekerjaan Umum dan Penataan Ruang & 2 \\
8 & Dinas Perumahan dan Permukiman & 2 \\
9 & Satuan Polisi Pamong Praja & 2 \\
10 & Dinas Pemadam Kebakaran & 2 \\
11 & Dinas Perhubungan & 2 \\
12 & Dinas Komunikasi, Informatika dan Statistik & 2 \\
13 & Dinas Kependudukan dan Pencatatan Sipil & 2 \\
14 & Dinas Koperasi, Usaha Kecil dan Menengah & 2 \\
15 & Dinas Kearsipan dan Perpustakaan & 2 \\
16 & Dinas Penanaman Modal dan Pelayanan Terpadu Satu Pintu & 2 \\
17 & Dinas Pengendalian Penduduk, KB, PP, dan Perlindungan Anak & 2 \\
18 & Dinas Pemberdayaan Masyarakat dan Desa & 2 \\
19 & Dinas Lingkungan Hidup & 2 \\
20 & Dinas Pemuda dan Olah Raga & 2 \\
21 & Dinas Pariwisata & 2 \\
22 & Dinas Kelautan dan Perikanan & 2 \\
23 & Dinas Pertanian & 2 \\
24 & Dinas Ketahanan Pangan & 2 \\
25 & Dinas Perindustrian dan Perdagangan & 2 \\
26 & Dinas Tenaga Kerja & 2 \\
27 & Badan Perencanaan Pembangunan Daerah & 2 \\
28 & Badan Kepegawaian Daerah dan Pengembangan SDM & 2 \\
29 & Badan Pengelolaan Keuangan dan Aset Daerah & 2 \\
30 & Badan Pendapatan Daerah & 2 \\
\hline Ber & Dung & 2 \\
\hline
\end{tabular}

Bersambung... 
Lanjutan Tabel. 2

\begin{tabular}{lll}
\hline 31 & Badan Penanggulangan Bencana Daerah & 2 \\
32 & Badan Kesatuan Bangsa dan Politik & 2 \\
33 & Rumah Sakit Umum Daerah Kabupaten Lombok Barat & 2 \\
34 & Kecamatan Batu Layar & 2 \\
35 & Kecamatan Gerung & 2 \\
36 & Kecamatan Gunung Sari & 2 \\
37 & Kecamatan Kediri & 2 \\
38 & Kecamatan Kuripan & 2 \\
39 & Kecamatan Labuapi & 2 \\
40 & Kecamatan Lembar & 2 \\
41 & Kecamatan Lingsar & 2 \\
42 & Kecamatan Narmada & 2 \\
43 & Kecamatan Sekotong & Jumlah \\
& & 2 \\
\hline
\end{tabular}

Sumber : Data Penelitian, 2019

Pengumpulan data yang digunakan adalah teknik pengumpulan data survei. Dengan menggunakan teknik pengumpulan data ini, data penelitian akan diperoleh melalui daftar pertanyaan (kuisioner). Kuisioner merupakan alat pengumpulan data yang efektif karena dapat diperolehnya data standar yang dapat dipertanggungjawabkan untuk keperluan analisis menyeluruh tentang karakteristik populasi yang diteliti (Supranto, 2000). Skala pengukuran variabel dalam penelitian ini menggunakan skala likert. Skala likert digunakan untuk mengukur sikap, pendapat, dan persepsi seseorang atau sekelompok orang tentang fenomena sosial (Sugiyono, 2012:93). Dalam menjawab skala likert ini, responden hanya memberi tanda misal checklist atau tanda silang pada jawaban yang dipilih sesuai pertanyaan. Kuesioner yang telah diisi responden perlu dilakukan penyekoran. Berikut ini adalah bobot penilaian pada skala likert seperti tampak pata tabel 3 sebagai berikut:

Tabel 3. Bobot Penilaian

\begin{tabular}{cc}
\hline Pertanyaan & Skor \\
\hline Sangat Setuju/Selalu & 5 \\
Setuju/Sering & 4 \\
Ragu-ragu/Kadang-kadang/Biasa Saja & 3 \\
Tidak Setuju & 2 \\
Sangat Tidak Setuju & 1 \\
\hline
\end{tabular}

Sumber : Sugiyono, 2012

Sumber data penelitian ini adalah data primer dan data sekunder. Data primer berupa jawaban para responden terhadap variabel-variabel yang digunakan dalam pertanyaan (kuesioner). Sedangkan, data sekunder adalah data yang diperoleh dari sumber dokumen yang dimiliki pemerintah Kabupaten Lombok Barat. Prosedur analisis data dengan mengelompokkan data berdasarkan variabel dan jenis responden, mentabulasi data berdasarkan variabel dari seluruh variabel, menyajikan data tiap variabel yang diteliti, melakukan perhitungan untuk menjawab rumusan masalah dan melakukan perhitungan untuk menguji hipotesis yang telah diajukan (Sugiyono, 2014:147). 
Analisis statistik deskriptif adalah statistika yang berfungsi untuk mendiskripsikan atau memberi gambaran terhadap obyek yang diteliti melalui data sampel atau populasi sebagaimana adanya, tanpa membuat kesimpulan yang berlaku umum (Sugiyono, 2006:21). Analisis statistik deskritif digunakan untuk mengetahui nilai rata-rata, minimum, maksimum dan standar deviasi dari variabel-variabel yang diteliti. Dalam penentuan nilai kategori maka dibuat interval kelas dengan rumus sebagai berikut (Nasehudin dan Ghozali, 2012:135)

Interval Kelas $=\frac{\text { Nilai Tertinggi }- \text { Nilai Terendah }}{\text { Jumlah Kelas }}$

Nilai tertinggi 5 dan nilai terendah 1, dibagi menjadi lima kelas sehingga didapatkan nilai interval kelas sebagai berikut:

Interval Kelas $=\frac{5-1}{5}=0,8$

Kriteria skor untuk lima kelas disajikan pada tabel kategori yang menunjukkan tentang skala interpretasi hasil pengukuran kuesioner yang dapat dilihat pada tabel 4 . berikut:

Tabel 4. Kategori Rentang Skala

\begin{tabular}{cc}
\hline Interval Kelas & Kategori \\
\hline 1,00 s.d $\leq 1,80$ & Sangat Buruk \\
1,81 s.d $\leq 2,60$ & Buruk \\
2,61 s.d $\leq 3,40$ & Sedang \\
3,41 s.d $\leq 4,20$ & Baik \\
4,21 s.d $\leq 5,00$ & Sangat Baik \\
\hline
\end{tabular}

Sumber : Nasehudin dkk. (2012:135)

Dalam kategori diatas menunjukkan bahwa tiap variabel yang menuju kearah yang baik maka nilainya semakin baik. Oleh karena itu semakin tinggi nilai yang ditunjukkan partisipasi anggaran, gaya kepemimpinan dengan job relvant infomation sebagai moderasi maka kinerja manajerial pada pemerintah Kabupaten Lombok Barat semakin baik.

Analisis data yang digunakan dalam penelitian ini adalah metode PLSSEM dengan bantuan program bantuan program Smart PLS versi 3.0. PLS-SEM bertujuan untuk menguji hubungan prediktif antar konstruk dengan melihat apakah ada hubungan atau pengaruh antar konstruk tersebut (Ghozali dan Latan, 2015). PLS merupakan metode analisis yang bersifat soft modeling karena tidak mengasumsikan data harus dengan pengukuran skala tertentu, yang berarti jumlah sampel dapat kecil $(<100$ sampel atau $=30)$. Tahapan analisis menggunakan PLS-SEM berdasarkan (Ghozali dan Latan, 2015), setidaknya harus melalui lima tahapan dan setiap tahapan akan berpengaruh terhadap tahapan berpengaruh terhadap tahapan selanjutnya. Tahapan analisis yaitu konseptualisasi model, menentukan metode analisis algoritma, menentukan metode resampling, menggambar diagram jalur, evaluasi model.

\section{HASIL DAN PEMBAHASAN}

Responden dalam penelitian ini adalah pejabat struktural pada Organisasi Perangkat Daerah (OPD) Kabupaten Lombok Barat. Masing-masing responden tersebut mengisi kuesioner yang disebar oleh peneliti ke masing-masing OPD pada pemerintah Kabupaten Lombok Barat mulai tanggal 18 Juli sampai dengan 
18 Agustus 2019, dari total 100 kuesioner yang disebar sebanyak 6 kuesioner tidak kembali dan kuesioner yang kembali sebanyak 94 kuesioner. Dari 94 kuesioner yang kembali terdapat 3 kuesioner tidak diisi oleh responden sehingga total kuesioner yang dapat diolah sebanyak 91 kuesioner atau 91\% dari total kuesioner yang disebar. Rincian kuesioner penelitian yang disebar sampai dengan kuesioner yang dapat diolah dapat dilihat pada tabel 5 sebagai berikut:

Tabel 5. Sebaran dan pengembalian kuesioner

\begin{tabular}{lcc}
\hline \multicolumn{1}{c}{ Keterangan } & Jumlah & Persentase \\
\hline Jumlah kuesioner yang disebarkan & 100 & \\
Jumlah kuesioner yang tidak kembali & 6 & \\
Jumlah kuesioner yang kembali & 94 & $94 \%$ \\
Tingkat respon & 3 & \\
Jumlah kuesioner yang tidak diisi lengkap/cacat & 91 & $91 \%$ \\
Jumlah kuesioner yang dianalisis lebih lanjut & & \\
Tingkat respon yang dapat diolah & &
\end{tabular}

Sumber : Data Penelitian, 2019

Jumlah responden dalam penelitian ini adalah 91 responden sehingga nilai $t_{\text {tabel }}$ diperoleh sebesar 1,987. uji dengan partial least square (PLS) yang merupakan salah satu metode statistik Structural Equation Modelling (SEM) berbasis varian. Penelitian (Latan dkk, 2016) dan (Siringoringo, 2015) dengan variabel moderasi, mengevaluasi hasil melalui memunculkan variabel interaksi. Variabel interaksi adalah variabel yang muncul karena proses perkalian dari variabel predictor dan variabel pemoderasi (moderating variable). Merujuk pada proses evaluasi tersebut, penelitian ini mengevaluasi model dengan memunculkan varibel interaksi. Evaluasi penelitian ini melalui 5 tahapan yaitu: 1) Evaluasi model pengukuran (outer model); 2) Evaluasi model struktural (inner model); 3) Evaluasi persamaan model; 4) Evaluasi model pemoderasi; 5) Menyimpulkan uji signifikansi model.

Outer Model pada prinsipnya adalah menguji indikator terhadap variabel laten atau dengan kata lain sejauh mana indikator dapat menjelaskan variabel laten. Proses evaluasi model pengukuran (outer model) melalui pengujian validitas dan reliabilitas, evaluasi validitas menggunakan convergent dan discriminant validity dan evaluasi reliabilitas menggunakan composite reliability.

Validitas konvergen berhubungan dengan prinsip bahwa mengukur dari satu variabel seharusnya berkolerasi tinggi. Outer model memenuhi syarat validitas konvergen untuk konstruk reflektif apabila nilai loading diatas 0.70 pada kondisi tertentu loading antara 0.4-0.7 harus tetap dipertimbangkan untuk dipertahankan dengan memperhatikan kontribusinya terhadap validitas (Hair dkk, 2014:101). Penelitian ini menggunakan nilai outer loading sebesar 0.5 pada tahapan pengujian evaluasi validitas.

Berdasarkan hasil analisis PLS algorithm diketahui bahwa masih terdapat 4 (empat) indikator memiliki nilai outer loading dibawah 0.5 sehingga harus didrop dari model karena memiliki nilai korelasi yang dikategorikan rendah sehingga tidak memenuhi syarat validitas konvergen untuk konstruk reflektif. Adapun empat indikator tersebut adalah 1) Indikator PA2 (Alasan penolakan penyusunan anggaran yang diajukan) pada variabel PA (Partisipasi Anggaran) dengan outer loading sebesar $0.191 ; 2$ ) Indikator KM5 (Pengawasan) pada variabel 
KM (Kinaerja Manajerial) dengan outer loading sebesar 0.154; 3) Indikator KM6 (Pemilihan Staf) pada variabel KM (Kinaerja Manajerial) dengan outer loading sebesar 0.453; 4) Indikator KM7 (Negosiasi) pada variabel KM (Kinaerja Manajerial) dengan outer loading sebesar -0.236.

Setelah emapat indikator di drop dari model karena memiliki nilai outer loading $<0.5$, selanjutnya data diolah kembali dengan PLS algorithm tahap kedua untuk melihat dan memastikan bahwa seluruh indikator memiliki korelasi yang tinggi dengan konstruk laten yang diwakilinya sehingga memenuhi persyaratan convergent validity yang ditunjukkan dengan nilai outer loading $>0.5$. Adapun hasil tahap kedua ditunjukan pada gambar 2. sebagai berikut:

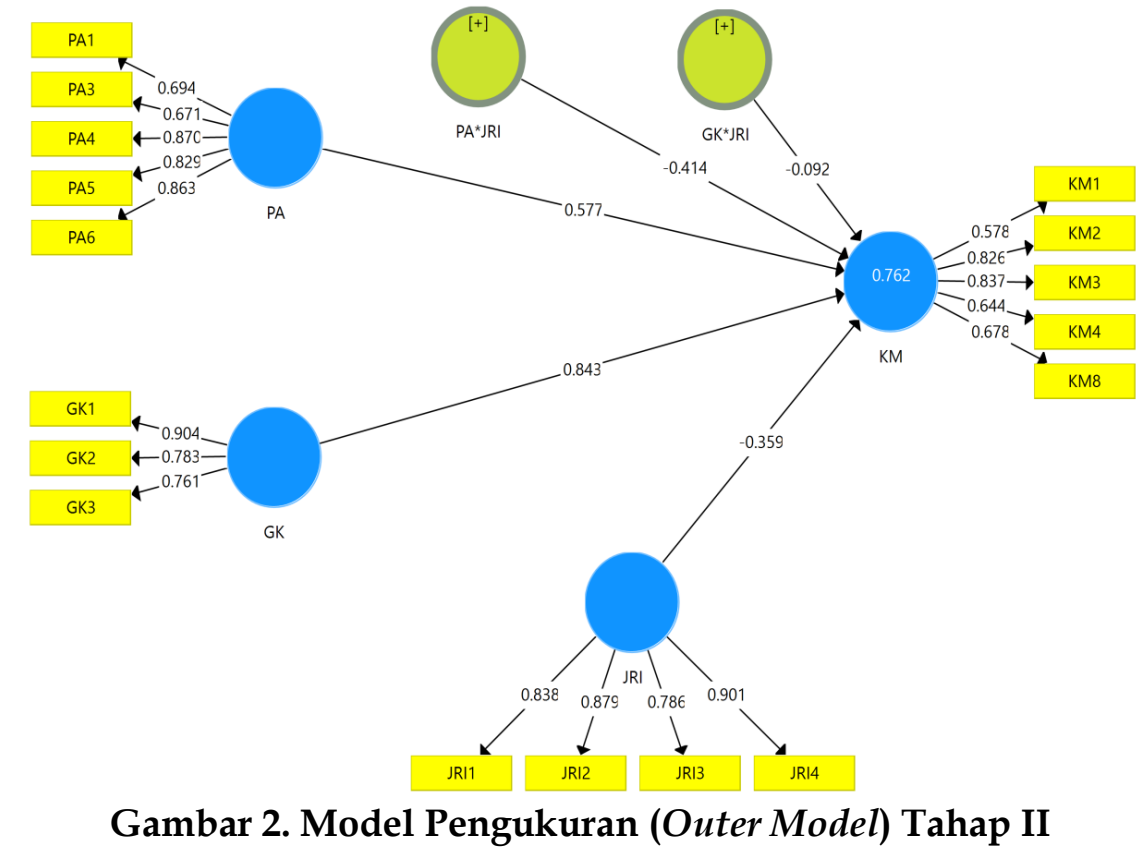

Sumber : Data Penelitian, 2019

Evaluasi konstruk Discriminant validity pada model pengukuran indikator reflektif dinilai berdasarkan cross loading untuk setiap variabel serta membandingkan nilai masing-masing akar kuadrat average variance extracted (AVE) terhadap nilai korelasi antar konstruk. Berdasarkan proses PLS algorithm, nilai loading indikator ke konstruk yang diukur lebih besar dibandingkan loading indikator tersebut ke konstruk lainnya. Hasil cross loading dapat dilihat pada nilai akar kuadrat AVE dapat dilihat pada tabel 6 sebagai berikut:

Tabel 6. Akar Kuadrat Average Variance Extracted (AVE) dan korelasi antar Konstruk

\begin{tabular}{ccccccc}
\hline & PA & GK & JRI & KM & PA*KM & GK*KM \\
\hline PA & 0.790 & & & & & \\
GK & 0.514 & 0.818 & & & & \\
JRI & 0.543 & 0.843 & 0.852 & & & \\
KM & 0.568 & 0.707 & 0.595 & 0.720 & & \\
PA*JRI & 0.460 & 0.231 & 0.121 & -0.103 & 1.000 & \\
GK*JRI & 0.236 & 0.178 & 0.109 & -0.024 & 0.346 & 1.000 \\
\hline
\end{tabular}


Sumber : Data Penelitian, 2019

Keterangan:

$\begin{array}{ll}\text { PA } & =\text { Partisipasi Anggaran } \\ \text { GK } & =\text { Gaya Kepemimpinan } \\ \text { JRI } & =\text { Job Relevant Information } \\ \text { KM } & =\text { Kinerja Manajerial } \\ \text { PA*JRI } & =\text { Moderasi Efek PA*JRI ke KM } \\ \text { GK*JRI } & =\text { Moderasi Efek GK*JRI ke KM }\end{array}$

Nilai cross loading menunjukkan nilai loading indikator ke konstruk yang diukur lebih besar dibandingkan loading indikator tersebut ke konstruk lainnya dan nilai kuadrat AVE lebih besar dari dari korelasi antar konstruk indikator telah memenuhi discriminant validity dan dinyatakan valid.

Evaluasi reliabilitas konstruk dilakukan untuk membuktikan akurasi, konsistensi dan ketepatan instrument dalam mengukur konstruk dengan menggunakan composite reliability. Evaluasi reliabilitas konstruk pada model pengukuran indikator reflektif dilakukan dengan crombach's alpha dan composite reliability. Namun demikian penggunaan crombach's alpha untuk menguji kostruk akan memberikan nilai yang lebih rendah (underestimate) sehingga lebih disarankan untuk menggunakan composite reliability. Aturan praktis rule of thumb yang biasa digunakan untuk menilai reliabiltas konstruk yaitu nilai composite reliability harus lebih dari 0.7 (Latan dkk, 2012:80). Hasil analisis PLS algorithm dengan melihat composite reliability disajikan pada tabel 7 sebagai berikut:

Tabel 7. Hasil Uji Reliabilitas

\begin{tabular}{lcc}
\hline \multicolumn{1}{c}{ Variabel } & Nilai Composite & Keterangan \\
\hline Partisipasi Anggaran & 0.891 & Reliabel \\
Gaya Kepemimpinan & 0.858 & Reliabel \\
Job Relevant Information & 0.914 & Reliabel \\
Kinerja Manajerial & 0.840 & Reliabel \\
Moderasi Efek PA*JRI & 1.000 & Reliabel \\
Moderasi Efek GK*JRI & 1.000 & Reliabel \\
\hline
\end{tabular}

Sumber : Data Penelitian, 2019

Berdasarkan hasil evaluasi composite reliability semua variabel memiliki nilai composite reliability $>0.70$ sehingga semua variabel dalam model penelitian ini dianggab reliable.

Inner model pada prinsipnya adalah untuk menguji hipotesis antara satu variabel dengan yang lainnya. Dalam menilai model struktural dengan PLS, dimulai dengan meliahat $\mathrm{R}$-Square $\left(\mathrm{R}^{2}\right)$ untuk setiap variabel endogen sebagai kekuatan prediksi dari model struktural. Selanjutnya melihat nilai $\mathrm{Q}-$ Square $\left(\mathrm{Q}^{2}\right)$ yang menunjukkan bahwa model memiliki predictive relevant $\left(\mathrm{Q}^{2}>0\right)$ dan terakhir melakukan uji hipotesis (uji t) yang dilakukan dengan menggunakan metode resampling bootstrapping. Nilai signifikansi yang dipakai pada level 5\% (0.05) atau t-value 1.987.

Nilai $\mathrm{R}$ Square $\left(\mathrm{R}^{2}\right)$ dugunakan untuk mengukur tingkat variasi perubahan variabel independen terhadap variabel dependen. Semaikin tinggi nilai $\mathrm{R}^{2}$ maka semakin baik model penelitian yang diajukan (Latan dkk, 2012:81). 
diketahui hasil evaluasi inner model untuk nilai $\mathrm{R}^{2}$ disajikan dalam tabel 8. sebagai berikut:

Tabel 8. Nilai R Square $\left(\mathbf{R}^{2}\right)$

\begin{tabular}{ccc}
\hline No & Hubungan Variabel & $\mathrm{R}$ Square $\left(\mathrm{R}^{2}\right)$ \\
\hline 1 & $\mathrm{PA}, \mathrm{GK}, \mathrm{JRI}, \mathrm{PA}^{*} \mathrm{JRI}, \mathrm{GK}{ }^{*} \mathrm{JRI} \rightarrow \mathrm{KM}$ & 0.762 \\
\hline
\end{tabular}

Sumber : Data Penelitian, 2019

Diketahui bahwa nilai $\mathrm{R}^{2}$ diperoleh dari hubungan Partisipasi Anggaran (PA), Gaya Kepemimpinan (GK), Job Relevant Information (JRI), interaksi PA*JRI, interaksi GK*JRI sebesar 0.762, hasil ini menunjukkan bahwa 76.2\% keragaman dari variabel Kinerja Manajerial mampu dijelaskan oleh variabel Partisipasi Anggaran (PA), Gaya Kepemimpinan (GK), Job Relevant Information (JRI), interaksi PA*JRI, interaksi GK*JRI dan sisanya sebesar $23.8 \%$ dijelaskan oleh variabel lain diluar dari penelitian.

Hasil pengujian hipotesis didapat dari pengujian bootstrapping dengan menggunakan bantuan software PLS 3.0. hasil pengujian disajikan pada gambar 3. sebagai berikut:

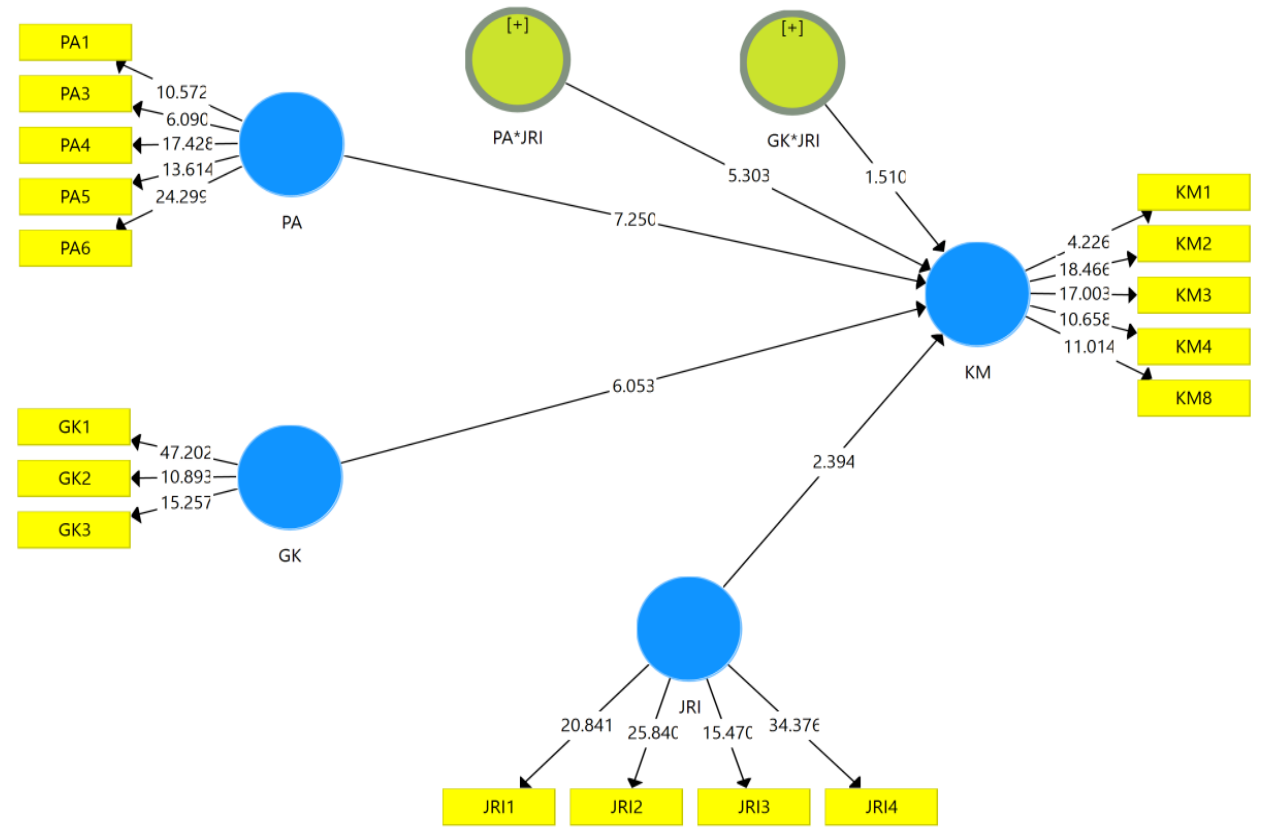

Gambar 3. Hasil Proses bootstrapping

Sumber : Data Penelitian, 2019

Path coefficient variabel PA ke KM dengan nilai sebesar 7.250, variabel GK ke KM dengan nilai sebasar 6.053, variabel JRI ke KM dengan nilai sebesar 2.394, interaksi PA*JRI ke KM dengan nilai sebesar 5.303 memiliki nilai path coefficient lebih besar dari t-table sebesar 1.987 artinya signifikan sementara variabel moderasi interaksi GK*JRI ke KM memiliki nilai path coefficient sebesar 1.510 lebih kecil dari t-table sebesar 1.987 yang berarti tidak signifikan dari proses bootstrapping. Untuk lebih jelasnya hasil path coefficient dapat dilihat pada gambar 4. 


\begin{tabular}{|c|c|c|c|c|c|c|}
\hline \multirow[t]{2}{*}{ Mean, STDEV } & T-Values, P-Va... & \multicolumn{2}{|c|}{ 㘣 Confidence Intervals } & \multicolumn{2}{|c|}{ Confidence Intervals Bias C... } & Samples \\
\hline & Original Sampl... & Sample Mean (... & Stand & ard Devia... & T Statistics $(\mid 0 . .$. & P Values \\
\hline GK*JRI -> KM & -0.092 & -0.100 & & 0.061 & 1.510 & 0.132 \\
\hline$P A^{\star} J R I->K M$ & -0.414 & -0.398 & & 0.078 & 5.303 & 0.000 \\
\hline $\mathrm{PA} \rightarrow \mathrm{KM}$ & 0.577 & 0.565 & & 0.080 & 7.250 & 0.000 \\
\hline GK $>$ KM & 0.843 & 0.808 & & 0.139 & 6.053 & 0.000 \\
\hline JRI $>$ KM & -0.359 & -0.317 & & 0.150 & 2.394 & 0.017 \\
\hline
\end{tabular}

Gambar 4. Path Coefficient (Mean, STDEV,T-Value, P-Value) Sumber : Data Penelitian, 2019

Nilai t-statistic dan p-value yang digunakan untuk mengukur keterdukungan hipotesis. Pada penelitian ini ukuran signifikan keterdukungan hipotesis menggunakan perbandingan nilai $t$-table dan $t$-statistic. Jika nilai $t$ statistic lebih besar dibanding dengan nilai $t$-table maka hipotesis diterima. Untuk tingkat keyakinan 95\% (alpha 5\%) maka nilai t-table untuk hipotesis berarah (onetailed) adalah lebih besar atau sama dengan 1.987. Dengan demikian dapat disimpulkan bahwa hipotesis pertama $\left(\mathrm{H}_{1}\right)$ dan hipotesis kedua $\left(\mathrm{H}_{2}\right)$ diterima, hipotesis ketiga $\left(\mathrm{H}_{3}\right)$ tidak terbukti karena memiliki hubungan yang tidak searah, sedangkan hipotesis keempat $\left(\mathrm{H}_{4}\right)$ ditolak karena memiliki $t$-statistic $<1.987$.

Menurut (Solimun, 2010:35) variabel pemoderasi dapat dikategorikan menjadi 4 (empat) jenis yaitu pure moderating (pemoderasi penuh), quasi moderating (pemoderasi semu), homologiser moderating (pemoderasi potensial), dan predictor moderating (pemoderasi sebagai prediksi).

Jenis pemoderasi dalam penilitaian ini adalah 1) Quasi moderating (pemoderasi semu) karena pengaruh variabel JRI ke KM signifikan dan pengaruh variabel interaksi PA*JRI ke KM juga signifikan; 2) Predictor moderating (pemoderasi sebagai prediksi) karena pengaruh variabel JRI ke KM signifikan sedangkan varibel interaksi GK*JRI ke KM tidak signifikan.

\section{SIMPULAN}

Hasil analisis data menunjukkan bahwa partisipasi anggaran dan gaya kepemimpinan berpengaruh positif dan signifikan terhadap kinerja manajerial. Temuan ini mengungkapkan bahwa keterlibatan individu dalam menyusun suatu anggaran yang meliputi kesempatan, kesesuaian anggaran dan implementasinya mampu meningkatkan kinerja manajerial. Begitu juga dengan gaya kepemimpinan pemerintahan Kabupaten Lombok Barat mampu mempengaruhi dan menggerakkan bawahannya sehingga bawahan akan bekerja lebih giat dan disiplin pada tugas yang pada akhirnya bisa meningkatkan kinerja manajerial pada OPD pemerintah Kabupaten Lombok Barat.

Job relevant information tidak mampu memperkuat pengaruh partisipasi anggaran terhadap kinerja manajerial. Hasil penelitian ini memberikan gambaran bahwa informasi tentang anggaran belum tentu diterima dengan baik sehingga tidak menutup kemungkinan kinerjapun selalu akan bertolak belakang dengan tujuan yang akan dicapai. Job relevant information tidak mampu 
memperkuat pengaruh gaya kepemimpinan terhadap kinerja manajerial. Hal ini berarti kebijakan yang ada pada setiap organisasi pada OPD pemerintah Kabupaten Lombok Barat seringkali berubah sehingga totalitas dalam bekerjapun rendah. Faktor lain yang menyebabkan kinerja manajerial tidak maksimal adalah seringnya mutasi jabatan sehingga bawahan harus menyesuaikan diri dengan pimpinan yang baru.

Beberapa saran dan keterbatasan dalam penelitian dalam meningkatkan kinerja manajerial perlu peningkatan pula pada penyelenggaraan diklat/pelatihan pada masing-masing bidang sehingga dapat meningkatkan kualitas dari penyelenggaraan layanan pada masyarakat. Selain itu peningkatan alokasi anggaran sangat dibutuhkan untuk membiayai program dan kegiatan unggulan oleh pemerintah yang sesuai dengan kebutuhan masyarakat.

Penelitian ini hanya sebatas pada peingkatan kinerja manajerial. Seperti yang diketahui kinerja manajerial sebatas pada fungsi manajerial yang mencakup perencanaan, investigasi, koordinasi, evaluasi, pengawasan, pemilihan staf, negosiasi dan perwakilan. Berdasakan karakteristik organisasi sektor publik yang berorientasi pada melayani masyarakat maka tujuan dari penyelenggaraan pemerintah melalui partisipasi anggaran, gaya kepemimpinan, job relevant information adalah untuk memberikan pelayanan terbaik kepada masyarakat. Berdasarkan uraian tersebut maka untuk penelitian selanjutnya dapat menguji pengaruh gaya kepemimpinan dan partisipasi anggaran terhadap tingkat kepuasan masyarakat.

\section{REFERENSI}

Adrianto, Yogi. 2008. "Analisis Pengaruh Partisipasi Penyusunan Anggaran Terhadap Kinerja Manajerial Dengan Kepuasan Kerja, Job Relevant Information Dan Kepuasan Kerja Sebagai Variabel Moderating (Studi Empiris Pada Rumah Sakit Swasta Di Wilayah Kota Semarang)." Universitas Diponegoro.

Anthony, Robert N., and Vijay Govindarajan. 2002. Sistem Pengendalian Manajemen (Terjemahan). Jakarta: Salemba Empat.

Argyris. 1952. “Organizational Leadership Dan Participation Management." The Journal of Business XXVII: 1-7.

As'ad. 1991. Seri Ilmu Manajemen Sumber Daya Manusia Psikologi Indsutri. Bandung.

Bahtiar Arif, Muchlis, and Iskandar. 2009. Akuntansi Pemerintahan. Jakarta: Akademia.

Baiman, S., and J.S. Demski. 1980. "Economically Optimal Performance Evaluation and Control Systems." Journal of Accounting Research: 184-228.

Basri, Yesi Mutia. 2010. "Pengaruh Penganggaran Partisipasi Dan Job Relevan Informationterhadap Budget Slack Pemerintah Provinsi Riau." Jurnal Ilmu Administrasi Negara 10(1).

Bernardin, H.J., and J.E.A. Russel. 1993. Human Resource Management Anexperiental Approach. Singapore: Mc Graw-Hill, Inc.

Brownell, p. 1982. "Participation in Budgeting Process: When It Works and When It Doesn't." Journal of Accounting Literature 1: 124-53.

De Coster, T. D., and P.J Fertakis. 1968. "Budget-Induced Pressure and Its 
Relationship to Supervisory Behavior." Journal of Accounting Research (Autumn): 237-46.

Cushway, Barry. 1996. Manajemen Sumber Daya Manusia (Perencanaan, Analysis, Kinerja, Penghargaan). Jakarta: PT. Elex Media Komputindo Kelompok Gramedia.

Dewi, Cokorda Istri Intan Paramita, and Gerianta Wirawan Yasa. 2017. "Pengaruh Partisipasi Anggaran Terhadap Kinerja Manajerial Dengan Organizational Citizenship Behavior Dan Komitmen Organisasi Sebagai Pemoderasi." E-Jurnal Akuntansi Universitas Udayana 21(2): 1519-48.

Dharma, Agus. 1992. Manajemen Personalia. keempat. Jakarta: Erlangga Jakarta.

Dianawati, Eris. 2009. "Pengaruh Partisipasi Penyusunan Anggaran Terhadap Kinerja Manajerial: Komitmen Organisasi Dan Job Related Stress Sebagai Variabel Intervening." Jurnal Ekonomi Modernisasi 5(1): 1-18.

Erwati, Misni. 2009. "Pengaruh Partisipasi Penyusunan Anggaran Berbasis Kinerja (ABK) Terhadap Kinerja Kepala Satuan Kerja Perangkat Daerah (SKPD) Pemerintah Daerah Dengan Komitmen Organisasi Dan Gaya Kepemimpinan Sebagai Variabel Moderating (Survey Pada Aparatur Pemerintah Ko." Jurnal Percikan 102.

Fazli, Muslim, and A. Djalil Muslim. 2006. "Pengaruh Orientasi Profesional Terhadap Konflik Peran: Interaksi Antara Partisipasi Anggaran Dan Penggunaan Anggaran Sebagai Alat Ukur Kinerja Dengan Orientasi Manajerial (Suatu Penelitian Empiris Pada Perguruan Tinggi Negeri Dan Swasta Di Provinsi Nanggr." BENEFIT 8(2).

Ferdinand, A. 2014. Metode Penelitian Manajemen (5th Ed.). Semarang: Universitas Diponegoro.

Fitri, Syarifah Massuki, Unti Ludigdo, and Ali Djamhuri. 2013. "Pengaruh Gaya Kepemimpinan, Komitmen, Organisasi, Kualitas Sumber Daya, Reward, Dan Punishment Terhadap Anggaran Berbasis Kinerja (Studi Empirik Pada Pemerintah Kabupaten Lombok Barat)." Jurnal Dinamika Akuntansi 5(2): 15771.

Garrison, and Noreen. 2000. Akuntansi Manajerial (Terjemahan). Jakarta: Salemba Empat.

Ghozali, I., and H. Latan. 2015. Konsep, Teknik, Aplikasi Menggunakan Smart PLS 3.0 Untuk Penelitian Empiris. Semarang: Universitas Diponegoro.

Ghozali, Imam. 2008. SEM Metode Alternatif Dengan PLS. Semarang: Universitas Diponegoro.

. 2011. Aplikasi Analisis Multivariate Dengan Program SPSS. Semarang: Universitas Diponegoro.

. 2014. Structural Equation Modeling, Metode Alternatif Dengan Partial Least Square (PLS). 4th ed. Semarang: Universitas Diponegoro.

Gunawan, Aditiya Christianto, and Linda Santioso. 2015. "Pengaruh Partisipasi Anggaran Terhadap Kinerja Motivasi Sebagai Variabel Moderating ( Studi Empiris Pada Perusahaan Manufaktur Di Jakarta Dan Tangerang )." Jurnal Akuntansi XIX(01): 144-59.

Hair, J.F., C.M. Ringle G.T.M. Hult, and M. Sartedt. 2014. A Primer on Partial Least Squares Structural Equation Modeling (PLS-SEM). United State: Inc. United State of America. 
Harianto.2018. Pelayanan Publik Kabupaten Lombok Barat Paling Buruk Di NTB. Diakses pada 2 April 2019, dari https://news.detik.com/berita/d4339460/ pelayanan-publik-kabupaten-lombok-barat-paling-buruk-di-ntb.

Hasibuan, malayu S.P. 2005. Manajemen Sumber Daya Manusia. Revisi. Jakarta: Bumi Aksara. 2006. Manajemen Sumber Daya Manusia. Revisi. Jakarta: Bumi Aksara.

Hasibuan, Malayu S.P. 2016. Manajemen: Dasar, Pengertian, Dan Masalah. Revisi. Jakarta: Bumi Aksara.

Hehanusa. 2010. "Pengaruh Partisipasi Penganggaran Terhadap Kinerja Aparat: Integrasi Variabel Intervening Dan Variabel Moderating Pada Pemerintah Kota Ambon Dan Pemerintah Kota Semarang." Universitas Diponegoro.

Indriantoro, Nur, and Bambang Supomo. 2002. Metodologi Penelitian Bisnis Untuk Akuntansi \& Manajemen. Yogyakarta: Universitas Gadjah Mada.

Indriyati, Endah Susetyo. 2017. “Pengaruh Gaya Kepemimpinan, Motivasi Dan Disiplin Kerja Terhadap Kinerja Karyawan Dengan Pemahaman Etika Kerja Islami." Jurnal Ilmu dan Riset Manajemen 1(2): 134-46. https://ejournal.stiesia.ac.id/jirm/article/viewFile/1533/1491.

James, Gibson L., M John Ivancevich, and Domnnelly H James. 2010. Organisasi Perilaku, Struktur Dan Proses. Jilid 1. Tangerang: Binarupa Aksara.

Jogiyanto. 1999. Analisis Dan Desain Sistem Informasi : Pendekatan Terstruktur Teori Dan Praktek Aplikasi Bisnis. Yogyakarta: ANDI Yogyakarta. . 2004. Metodologi Penelitian Bisnis. 2004/2005. Yogyakarta: Universitas Gadjah Mada.

Kren, Leslie. 1992. "Budgetary Participation and Managerial Performance: The Impact of Information and Environmental Volatility." The Accounting Review 67(3).

Latan, H., and L. Ghozali. 2012. Partial Least Square "Konsep, Teknik Dan Aplikasi :Smart PLS 2.0 M3.

Latan, H., C. Jose, and C.M. Ringle Ringle. 2016. "Whistleblowing Intentions Among Public Accountants in Indonesia: Testing for the Moderation Effect." Journal of Business Ethics 19(10): 34-55.

Locke, E. A., and G. P. Latham. 1990. A Theory of Goal Setting and Task Performance. Englewood Cliffs: Prentice-Hall.

Mahoney. 1963. Development of Managerial Performance: A ResearchApproach. South Western Publishing.

Mardiasmo. 2002. "Otonomi Daerah Sebagai Upaya Memperkokoh Basis Perekonomian Daerah." Artikel Th.1 (4). 2009. Akuntansi Sektor Publik. Yogyakarta: ANDI Yogyakarta.

Maria, Niken Setyarini, and Susty A Anastasia. 2008. "Pengaruh Partisipasi Anggaran Terhadap Kinerja Manajerial Dengan Komitmen Organisasi Sebagai Variabel Intervening Pada Bank Perkreditan Rakyat." Universitas Atma JayaYogyakarta.

Mowen, and Hansen. 2013. Akuntansi Manajerial. Jakarta: Salemba Empat.

Nasehudin, Toto, and N. Gozali. 2012. Metode Penelitian Kuantitatif. Bandung: Pustaka Setia.

Nazaruddin, Ietjie, and Henry Setyawan. 2012. "Pengaruh Partisipasi Anggaran Terhadap Kinerja Aparat Pemerintah Daerah Dengan Budaya Organisasi, 
Komitmen Organisasi, Motivasi, Desentralisasi, Dan Job Relevant Information (JRI) Sebagai Variabel Moderasi." Jurnal Akuntansi dan Investasi 12(2): 197-207.

Nusra media.2019. Penilaian Ombusdman RI, Dinas Dukcapil Lobar Masuk Kategori Kuning! - Nusra Media. Diakses pada 18 Juni 2019, dari https://www.nusramedia.com/pemerintahan/ penilaian-ombusdman-ridinas-dukcapil-lobar-masuk-kategori-kuning-5002.html.

Puspaningsih, Abriyani. 1998. "Pengaruh Partisipasi Dalam Penyusunan Anggaran Terhadap Kepuasan Kerja Dan Kinerja Manajer : Role Ambiguity Sebagai Variabel Antara." Yogyakarta.

Putri, Zuwesty Eka, and Ricky Adiguna. 2014. "Pengaruh Partisipasi Anggaran, Komitmen Organisasi, Gaya Kepemimpinan Terhadap Kinerja Manajerial." Jurnal Bisnis dan Manajemen 4(3): 137-60.

Rido, M Rosyid. 2019. Serius Perbaiki Pelayanan Publik, Bupati Lombok Barat Undang Ombudsman. Diakses pada 25 Juni 2019, dari https://www.ombudsman.go.id/artikel/r/artikel--serius-perbaikipelayanan-publik-bupati-lombok-barat-undang-ombudsman

Riduwan. 2009. Metode Dan Teknik Menyusun Tesis. Cetakan ke. ed. Zaenal M.T. Arifin. Bandung: ALFABETA.

Robbins, Stephen P. 2006. Perilaku Organisasi. Jakarta: PT. Prenhalindo.

Saputra, Andri, and Rizky Natassia. 2014. "Pengaruh Gaya Kepemimpinan Dan Motivasi Kerja Terhadap Kinerja Karyawan Badan Pusat Statistik (BPS) Kota Padang." Journal of Economic and Economic Education 2(2): 134-43.

Satria, R. Okky, and Husaeri Priatna. 2012. "Pengaruh Gaya Kepemimpinan, Komitmen Dan Kepuasan Kerja Terhadap Kinerja Karyawan." 6(2): 85-93.

Schiff, M., and A.W. Lewin. 1970. "The Impact of People on Budgets." The Accounting Review 45: 259-68.

Siegel, G., and H.R. Marconi. 1989. Behavioral Accounting. Co. Cincinnati, OH.

Siringoringo, W. 2015. "Pengaruh Penerapan Good Governance Dan Whistleblowing System Terhadap Kepatuhan Wajib Pajak Orang Pribadi Dengan Resiko Sanksi Pajak Sebagai Variabel Moderating." Jurnal Akuntansi 19(2): 207-24.

Soedjono. 2005. "Pengaruh Budaya Organisasi Terhadap Kinerja Organisasi Dan Kepuasan Kerja Karyawan Pada Terminal Penumpang Umum Di Surabaya." Jurnal Manajemen dan Kewirausahaan 7(1): 22-47.

Soleman, Rusman. 2012. "Pengaruh Penganggaran Partisipatif Terhadap Kinerja Manajerial Dengan Budaya Organisasi Dan Gaya Kepemimpinan Sebagai Variabel Moderating." Jurnal Siasat Bisnis 16(1): 87-105.

Solimun. 2010. Analisis Variabel Moderasi Dan Mediasi. Malang.

Sucitrawati, I Gusti Ayu, and Maria M Ratna Sari. 2017. "Pengaruh Partisipasi Penganggaran Terhadap Kinerja Manajerial Dengan Budaya Organisasi Dan Job Relevant Information Sebagai Pemoderasi." E-Jurnal Akuntansi Universitas Udayana 20(3): 1791-1819.

Sugiyono. 1999. Metode Penelitian Bisnis. Bandung: CV Alfabeta. 2006. Metode Penelitian Bisnis. Bandung: CV Alfabeta.

2012. Metode Penelitian Kuantitatif, Kualitatif Dan RED. Bandung: ALFABETA. 
2013. Metode Penelitian Kuantitatif, Kualitatif Dan RED. Bandung: ALFABETA.

2014. Metode Penelitian Kuantitatif, Kualitatif Dan RED. Bandung: ALFABETA.

Supranto. 2000. Metode Riset: Aplikasinya Dalam Pemasaran. Jakarta: Rineka Cipta,Jakarta.

Supriyono, R.A. 2006. "Pengaruh Variabel Perantara Komitmen Organisasi Dan Partisipasi Penganggaran Terhadap Hunbungan Antara Usia Dan Kinerja Manajer Di Indonesia." Jurnal Ekonomi dan bisnis 6(1): 31-35.

Tjiptono, Fany, and Diana Anastasia. 2003. Total Quality Management. Yogyakarta: ANDI Yogyakarta.

Umayah, Arlina Delas. 2015. "Pengaruh Sistem Reward, Job Relevant Information (JRI), Danmanager's Value Orientation Towards Innovation(Voi Manajer) Terhadap Kinerja Karyawan Melalui Kepuasan Kerja Sebagai Variabel Intervening (Studi Kasus Pada Kantor Pusat PT WIKA Gedung Jakarta)." Universitas Negeri Yogyakarta.

Vebiyana, Siregar. 2003. “Hubungan Partisipasi Anggaran Dengan Informasi Job Relevant Serta Pengaruhnya Terhadap Kepuasan Kerja Dan Kinerja Manajerial Di Lingkungan Pemerintah Yogyakarta." Universitas Gadjah Mada Yogyakarta.

Yeh, Quey-Jen. 1996. "The Link between Managerial Style and The Job Characteristic of the R \& D Professionals." $R$ \& D Management 26(1): 127-40.

Yusfaningrum, K., and Imam Ghozali. 2005. “Analisis Pengaruh Partisipasi Anggaran Terhadap Kinerja Manajerial Melalui Komitmen Tujuan Anggaran Dan Job Relevant Information (JRI) Sebagai Variabel Intervening." Simposium Nasional Akuntansi 8, Padang. 